\title{
PERWUJUDAN TINDAK KESANTUNAN BERKOMENTAR PADA WACANA MEDIA SOSIAL INSTAGRAM (The embodiment of Politeness Acts Commenting on Instagram Social Media Discourse)
}

\author{
Hari Kusmanto \\ Sekolah Pascasarjana, Magister Pendidikan Bahasa Indonesia \\ Universitas Muhammadiyah Surakarta \\ Jalan A. Yani Tromol Pos 1, Kartasura, Surakarta, Indonesia \\ Pos-el: harikusmanto.ums@gmail.com
}

(Naskah Diterima Tanggal: 5 Oktober 2019; Direvisi Akhir Tanggal:1 November 2019;

Disetujui Tanggal: 7 November 2019)

\begin{abstract}
This research aims to describe the embodiment of politeness commenting followers of Jokowi's Instagram account. The research data is the followers' comments on Jokowi's Instagram account that has politeness value. The data source is the follower comments on Jokowi's Instagram account. The collecting data on this research uses the documentation and scrutinizing followed method by a competent free engagements $(S B L C)$. Data analysis uses the intralingual and referential methods. The result of the research shows that the embodiment of politeness commenting that can be chosen to build a generation of character on media is to pay attention to the wishes of the speech partner, show confidence, use identity markers, give questions that are not trapping, involve the speech partners in speech activities, and intensify attention to the speech partners in speech. Citizens in commenting should use polite language and avoid using abusive language that triggers hostility.
\end{abstract}

Keywords: politeness commenting; social media; instagram

\begin{abstract}
Abstrak
Penelitian ini bertujuan untuk mendeskripsikan perwujudan kesantunan berkomentar followers akun Instagram Jokowi. Data penelitian ini berupa komentar-komentar followers dalam akun instagram Jokowi yang memiliki nilai kesantunan. Sumber datanya adalah komentar followers dalam akun instagram Jokowi. Pengumpulan data dalam penelitian ini menggunakan metode dokumentasi dan metode simak dilanjutkan dengan teknik simak bebas libat cakap (SBLC). Analisis data dalam penelitian ini menggunakan metode intralingual dan referensial. Hasil penelitian menunjukkan wujud kesantunan berkomentar yang dapat dipilih untuk membangun generasi berkarakter dalam bermedia adalah memperhatikan keinginan mitra tutur, menunjukkan rasa percaya diri, menggunakan penanda identitas, memberikan pertanyaan yang tidak menjebak, melibatkan mitra tutur dalam aktivitas tuturan, dan mengintensifkan perhatian kepada mitra tutur dalam tuturan. Warganet dalam berkomentar hendaknya menggunakan bahasa-bahasa yang santun dan menghindari penggunaan bahasa kasar yang memicu permusuhan.
\end{abstract}

Kata kunci: kesantunan berkomentar; media sosial; instagram

\section{PENDAHULUAN}

Karakter menjadi penting mendapatkan perhatian dari berbagai pihak, yakni orang tua, guru, dan tanpa terkecuali masyarakat pada umumnya. Ihwal karakter warganet dalam bermedia sosial sangat memprihatinkan. Warganet dalam bermedia sosial banyak melakukan tindakan-tindakan yang tidak bermoral atau tidak berkarakter. Dalam konteks media sosial, salah satu tindakan yang tidak mencerminkan warganet yang berkarakter adalah penggunaan bahasa yang tidak santun. Berikut ini bentuk-bentuk berbahasa dalam media sosial yang tidak mencerminkan warganet yang berkarakter, sarkasme (Nugraha, 2017; Iskandar et.al 2018), penggunaan kata-kata 
kasar (Ulum \& Kusmanto, 2018), penggunaan ungkapan vulgar (Setiawaty et.al 2018), mengecam, menghina, dan menyudutkan mitra tutur (Kusmanto \& Purbawati, 2019:217).

Realisasi kesantunan bermedia sosial sebagai merupakan hal yang penting. Hal ini dilatarbelakangi oleh hasil survei pengguna media sosial yang mengalami peningkatan setiap tahunnya. Pengguna media sosial di Indonesia mengalami peningkatan yang signifikan. Berdasarkan data yang dikeluarkan oleh Asosiasi Penyelenggara Jasa Internet Indonesia (AJPII) dalam kurun waktu tiga tahun terakhir pengguna internet mengalami peningkatan. Pengguna internet pada tahun 2015 sebanyak 110, 2 juta pengguna, 2016 sebanyak 132, 7 juta, dan pada tahun 2017 sebanyak 143, 26 juta (AJPII, 2017:1). Data tersebut menunjukkan terjadinya peningkatan penggunaan internet oleh masyarakat.

Adapun konten media sosial yang sering dikunjungi pengguna internet adalah facebook, instagram, youtube, google+, twiter, dan Linked In. Berdasarkan data yang dikeluarkan oleh AJPII, penggunaan konten media paling banyak adalah facebook sebanyak 71,6 juta atau 54\%, kedua instagram sebanyak 19,9 juta atau 15\%, ketiga youtube sebanyak 14,5 juta atau $11 \%$, keempat google + sebanyak 7.9 juta atau $6 \%$, kelima twiter sebanyak 7,2 juta atau $5,5 \%$, dan lingked in sebanyak 796 ribu atau 0,6\% (AJPII, 2016).

Berdasarkan data yang telah disajikan di atas, tindak kesantunan dalam bermedia sosial khususnya berkomentar merupakan hal yang penting dalam berkomunikasi. Implikasi tindak kesantunan bermedia sosial mampu menciptakan komunikasi yang harmonis dan saling menghargai. Hal ini termasuk dalam berkomentar apabila diwujudkan dengan kesantunan akan lebih baik. Inti dari sebuah komentar adalah konten yang ingin disampaikan diterima oleh mitra tutur.

Penelitian yang berkaitan dengan kesantunan pada media sosial pernah dilakukan oleh beberapa ahli sebagai berikut:
Praptiningsih \& Handayani (2017) hasil penelitiannya menunjukkan bahwa media sosial berfungsi sebagai dakwah yang mendidik, meluruskan informasi, pembaharu, pemersatu, dan perjuangan. Perlu adanya revitalisasi dakwah online dalam menghadapi tantangan bagi masyarakat infomasi. Berdasarkan hal tersebut, kesantunan berbahasa dalam dakwah online menjadi penting, melalui kesantunan bermedia mampu mendidik, memberikan informasi secara akurat dan faktual, dan melalui kesantunan bermedia dapat mempersatukan.

Penelitian mengenai kesantunan dalam bermedia sosial selanjutnya dilakukan oleh Rahmi (2017). Penelitian Rahmi menyimpulkan bahwa kesantunan dalam berita di media sosial sudah direalisasikan dengan cara pemilihan diksi, salah satunya mengkritisi tanpa menyakitkan. Rahmi dalam penelitian tersebut juga memberikan saran supaya perlu adanya keseimbangan dan menghormati asas praduga tak bersalah. Permasalahan tersebut salah satunya dapat diselesaikan dengan cara memperhatikan kesantunan berkomunikasi.

Penelitian yang selanjutnya dilakukan Sandra \& Dewi (2019) dalam penelitiannya menemukan etika komunikasi yang baik dalam media sosial adalah jangan menggunakan kata kasar, provokatif, porno atau pun sara; jangan mengunggah artikel atau status yang bohong; jangan meng-copy paste artikel atau gambar yang mempunyai hak cipta, serta memberikan komentar yang relevan.

Penelitian yang telah dilakukan oleh beberapa ahli tersebut di atas terbatas pada transformasi fungsi media sosial, etika bermedia sosial, dan kesantunan berbahasa. Padahal, kesantunan berbahasa tidak hanya terbatas pada kesantunan berbahasa. Lebih lanjut kesantunan merupakan kompetensi interpersonal dalam berkomunikasi. Kesantunan dapat dilihat melalui konteks tuturan tersebut disampaikan. Penelitian ini akan membahas mengenai kesantunan berkomentar dengan tidak hanya terbatas pada kesantunan berbahasa. 
Berdasarkan latar belakang di atas, masalah yang dibahas dalam penelitian ini adalah bagaimana bentuk-bentuk kesantunan berkomentar di media sosial (instagram) sebagai media membangun generasi yang berkarakter Tujuan penelitian ini adalah mendeskripsikan bentuk-bentuk kesantunan berkomentar sebagai upaya membangun generasi berkarakter. Manfaat penelitian ini diharapkan dapat memberikan sumbangan untuk pengembangan teori linguistik pada umumnya, dan sebagai contoh kesantunan dalam berkomentar khususnya media sosial instagram.

\section{KERANGKA TEORI}

Kesantunan berbahasa merupakan perilaku yang terjalin antara penutur dan mitra tutur. Kesantunan sebagai sebuah perilaku komunikasi yang harus memperhatikan etika. Hal ini sesuai dengan yang dikemukakan Zamzani et.al (2011:35) bahwa kesantunan (politeness) sebagai perilaku yang diekspresikan melalui cara yang baik atau beretika. Cara yang baik atau etika yang dimaksud di atas adalah etika dalam berkomunikasi.

Syaifudin (2017: 57) menyatakan kesantunan secara umum berhubungan dengan orang lain atau mitra tutur dalam sebuah komunikasi. Seorang penutur dan mitra tutur dalam berkomunikasi dapat berjalan dengan baik apabila di antara penutur dan mitra tutur melaksanakan kaidah atau konvensi kesantunan berbahasa. Pada dasarnya kesantunan berbahasa merupakan norma yang harus dipatuhi oleh penutur dan mitra tutur dalam suatu komunikasi. Kesantunan berbahasa merupakan adat sopan santun dalam bertutur kata yang baik yang menghubungkan daya dan makna (Kusno \& Rahman, 2016). Hal ini menunjukkan kesantunan berbahasa merupakan komunikasi yang mengikat antara penutur dan mitra tutur dalam suatu komunikasi untuk menggunakan kaidah bahasa yang santun atau kesantunan berbahasa.

Doko \& Warmadewa (2017: 161) menjelaskan kesantunan berbahasa memiliki perangkat kaidah tindak tutur yang menuntun jalannya suatu tindak tutur dan para penuturnya apakah mereka mematuhi atau melanggar kaidah kesantunan berbahasa. Apabila di antara penutur dan mitra dalam suatu komunikasi melanggar kaidah kesantunan berbahasa, dapat dikatakan penutur tersebut menggunakan bahasa yang tidak santun. Ketidaksatunan berbahasa akan menimbulkan komunikasi yang kurang baik, bahkan tujuan komunikasi tidak dapat tercapai. Hal ini diperkuat dengan pendapat Hamidah (2017: 1) bahwa ketidaksantunan berbahasa dalam komunikasi akan mengakibatkan tidak terjalinnya hubungan yang harmonis dan komunikasi yang dilakukan menjadi tidak efektif.

Selain itu, pemakaian bahasa yang santun dan tidak santun dalam berkomunikasi akan menunjukkan karakter seorang pemakai bahasa. Apabila seseorang penutur menggunakan bahasa yang santun, dapat dikatakan penutur tersebut memiliki karakter yang baik, begitu pula sebaliknya. Pada dasarnya bahasa menunjukkan karakter seorang penutur. Melalui bahasa yang digunakan penutur, menunjukkan kepribadian seseorang (Cahyaningrum, 2018).

Kesantunan berbahasa tidak lain adalah tata cara berbahasa yang sesuai dengan budaya, kesantunan berbahasa menunjukkan penghormatan terhadap mitra tutur. Akbar (2017: 97) mengungkapkan penggunaan bahasa yang baik, sopan beradab, merupakan cermin kepribadian mulia dan menunjukkan penghormatan kepada mitra tutur. Tujuan seorang penutur menggunakan bahasa yang santun sebagai strategi penghormatan terhadap mitra tutur. Hal ini sesuai dengan yang dikemukakan Febriadina et.al (2018: 75) salah satu tujuan berbahasa dengan baik dan santun merupakan salah satu cara seseorang penutur untuk menghormati mitra tutur dalam suatu komunikasi.

Semakin santun seorang penutur dalam berkomunikasi semakin mudah mencapai tujuan komunikasi. Adapun manfaat pemakaian bahasa yang santun dalam berkomunikasi 
dikemukakan Kurniadi et.al (2018: 2) yang meliputi manfaat bagi diri penutur, lingkungan tuturan, dan pendengar tuturan. Manfaat bagi penutur komunikasi akan menjadi lebih arif, lingkungan tuturan pun akan menjadi lebih kondusif.

Realisasi kesantunan berbahasa dapat dilakukan melalui dua strategi, yakni kesantunan positif dan negatif. Kuntarto (2016: 60) menyatakan kesantunan positif adalah tindakan penyeimbangan yang diarahkan untuk menjaga muka positif mitra tutur, yang dilakukan penutur dengan cara menunjukkan bahwa penutur menghargai keinginan dan kebutuhan mitra tutur.

Perwujudan kesantunan positif menurut Brown dan Levinson (dalam Fauziati, 2016: 149-150) diwujudkan melalui lima belas kesantunan yang meliputi: (1) memperhatikan keinginan, kesukaan, dan kebutuhan mitra tutur; (2) memberikan perhatian; kesetujuan, dan simpati mitra tutur; (3) mengintensifkan perhatian penutur dengan cara mendramatisasi peristiwa dan fakta; (4) menggunakan penanda identitas; (5) mencari persetujuan; (6) menghindari ketidaksetujuan dengan mitra tutur; (7) menunjukkan kesamaan dengan mitra tutur (8) menggunakan lelucon dalam berkomunikasi; (9) menunjukkan paham dengan mitra tutur saat berkomunikasi; (10) menunjukkan sikap optimis; (11) melibatkan mitra tutur dalam aktivitas tuturan; (12) memberi pertanyaan atau meminta alasan; (13) memberikan tawaran atau janji; (14) menyatakan hubungan resiprokal; dan (15) memberikan hadiah.

Berdasarkan uraian yang telah disajikan di atas, penelitian ini bertujuan mendeskripsikan perwujudan tindak kesantunan berkomentar followers akun Instagram Jokowi. Implikasi penelitian ini dapat dijadikan sebagai pedoman dalam menyampaikan saran, masukan, komentar, dan kritik secara santun baik secara langsung maupun dengan sarana media sosial (Kusmanto, 2019: 130).

\section{METODE}

Zurqoni, dkk. (2019). Penelitian kualitatif dalam penelitian ini bertujuan untuk menghasilkan deskripsi data berupa bentukbentuk kesantunan dalam berkomentar pada media sosial instagram Jokowi. Sesuai dengan penelitian kualitatif data dalam penelitian ini bukanlah angka-angka, melainkan berupa kata-kata komentar akun instagram Jokowi yang memiliki nilai kesantunan. Sesuai dengan data dalam penelitian ini, sumber data dalam penelitian ini adalah komentar akun instagram Jokowi periode Oktober-November 2018 sebagai suatu periode politik yang dilihat dari perspektif pemakaian bahasa sebagai sumbangan dalam bermedia sosial.

Pengumpulan data dalam penelitian ini menggunakan metode dokumentasi, simak, dan dilanjutkan dengan teknik catat. Dokumentasi yang dimaksud dalam penelitian ini adalah berupa komentar-komentar followers dalam akun instagram Jokowi. Teknik simak dilakukan dengan cara peneliti menyimak dengan sungguh-sungguh, baik bahasa tulis maupun lisan. Selanjutnya dilakukan teknik pencatatan, yakni melakukan pencatatan data sesuai dengan bentuk-bentuk kesantunan dalam berkomentar.

Analisis data dalam penelitian ini menggunakan metode padan intralingual (Mahsun, 2014: 259) dan padan referensial (Sudaryanto, 2015: 15). Metode padan intralingual dalam penelitian ini digunakan untuk mengidentifikasi bentuk-bentuk positif pada komentar-komentar akun instagram Jokowi. Metode padan referensial dalam penelitian ini digunakan untuk mengidentifikasi konteks komentar pada instagram Jokowi yang dapat ditelusuri melalui instagram Jokowi.

\section{PEMBAHASAN}

Berdasarkan data yang diperoleh berupa komentar akun instagram Jokowi, ditemukan beberapa bentuk komentar positif. Komentarkomentar positiftersebut dapat digunakan sebagai contoh bermedia sosial. Memberikan komentar 
secara santun merupakan pencerminan karakter seorang penutur. Oleh karena itu, kesantunan dalam bermedia khususnya berkomentar dapat dijadikan sebagai referensi membangun generasi berkarakter. Kesantunan positif yang dapat dijadikan contoh untuk membangun generasi berkarakter adalah sebagai berikut.

\section{Perwujudan Kesantunan Berkomentar}

\begin{tabular}{lll}
\hline No & Wujud Kesantunan Berkomentar \\
\hline 1 & \multicolumn{2}{l}{ Memperhatikan keinginan, mitra tutur } \\
\hline 2 & Menunjukkan rasa percaya diri \\
\hline 3 & \multicolumn{2}{l}{ Menggunakan penanda identitas } \\
\hline 4 & Memberikan pertanyaan & \\
\hline 5 & $\begin{array}{l}\text { Melibatkan mitra tutur dalam aktivitas } \\
\text { tuturan }\end{array}$ \\
\hline 6 & $\begin{array}{l}\text { Mengintensifkan perhatian kepada } \\
\text { mitra tutur }\end{array}$ \\
\hline
\end{tabular}

Berdasarkan uraian di atas terdapat enam bentuk kesantunan positif yang dapat dijadikan referensi untuk membangun generasi berkarakter. Komentar-komentar tersebut di atas diperoleh dari akun instagram Jokowi. Berikut ini pembahasan bentuk-bentuk kesantunan positif bermedia.

\section{Menunjukkan Perhatian Mitra Tutur dalam Berkomentar}

Membangun karakter dalam bermedia sosial dapat dilakukan dengan memperhatikan keinginan mitra tutur. Hal tersebut dapat direalisasikan dengan komentar-komentar yang mendukung mitra tutur dalam media sosial. Berikut ini komentar yang menunjukkan rasa percaya diri.

(1) Sehat selalu pak Jokowi. May Allah Bless' You... (hamdi_putra_ahmad, 19-10-2018) Konteks: Jokowi bertemu dengan Sekretaris Jenderal PBB Antonio Guterres. Sekjen PBB menyampaikan dukacita mendalam bagi para korban bencana gempa dan tsunami di Sulawesi Tenggara dan Lombok.
Tuturan data (1) merupakan komentar pemilik akun instagram hamdi_putra_ahmad yang mengomentari postingan Jokowi mengenai pertemuannya dengan Sekjen PBB. Komentar tersebut menunjukkan kesantunan positif dengan memperhatikan mitra tutur. Hal tersebut terlihat pada tuturan Sehat selalu pak Jokowi yang menunjukkan perhatian penutur terhadap kesehatan Jokowi. Tuturan demikian dapat dipilih oleh pengguna media sosial dalam berkomentar untuk membangun karakter literasi humanitas dalam bermedia.

Memperhatikan keinginan mitra tutur merupakan tuturan yang memiliki etika yang baik dalam bermedia sosial. Mengingat bahwa tindak kesantunan di media sosial yang masih rendah perlu adanya praktik pemakaian bentukbentuk tuturan yang bernilai kesantunan seperti pada data di atas.

Memperhatikan mitra tutur dalam berkomunikasi sebagai salah satu karakter yang perlu ditanamkan kepada pengguna media sosial. Hal ini dimaksudkan untuk mengembangkan karakter peduli kepada sesama. Karakter kepedulian dalam kehidupan berbangsa dan bernegara sangat penting dilakukan untuk membangaun keadilan dan kesejahteraan bersama.

Melalui karakter kepedulian seseorang akan mampu menjadi pengguna media sosial yang bijaksana dan pada akhirnya akan terwujud literasi media berbasis literasi humanitas. Karakter peduli sebagai sikap mengindahkan pengguna media sosial yang lainnya. Adapun nilai-nilai karakter peduli dalam media sosial meliputi toleransi, demokratis, saling mengingatkan, dan cinta damai.

\section{Menunjukkan Rasa Percaya Diri Mitra Tutur dalam Berkomentar}

Bentuk komentar yang bernilai karakter selanjutnya adalah komentar yang memberikan rasa percaya diri atau optimisme. Hal tersebut dapat direalisasikan dengan komentar-komentar yang mendukung mitra tutur dalam media 
sosial. Berikut ini komentar yang menunjukkan rasa percaya diri.

(2) Bapak presiden Jokowi begitu tulus melayani rakyatnya. Karena hanya beliau saat ini yang mampu memimpin negeri ini menjadi negara yang maju dan disegani negara manca. (ernamelon, 1110-2018)

Konteks: Jokowi bertemu dengan Sekretaris Jenderal PBB Antonio Guterres. Sekjen PBB menyampaikan duka cita mendalam bagi para korban bencana gempa dan tsunami di Sulawesi Tenggara dan Lombok.

Tuturan data (2) merupakan komentar yang menumbuhkan semangat dan rasa percaya diri baik oleh penutur maupun mitra tutur. Hendaknya dalam bermedia sosial seseorang memberikan komentar-komentar yang membangun, salah satunya dengan memberikan komentar yang menunjukkan rasa percaya diri terhadap yang telah dilakukan oleh mitra tutur. Ungkapan berorientasi percaya diri sebagai salah satu perwujudan kesantunan dalam memberikan komentar.

Melalui tuturan yang bermakna percaya diri akan mampu membuat mitra tutur lebih termotivasi dalam melakukan aktivitasnya. Oleh karena itu, sebaiknya dalam berkomentar menggunakan narasi-narasi yang membangun sikap percaya diri.

Begitu pula sebaliknya apabila komentarkomentar yang disajikan adalah komentar merendahkan tanpa alasan yang benar yang terjadi adalah mitra tutur menjadi tidak semangat. Bahkan lebih lanjut, komentar yang merendahkan mitra tutur dapat memicu konflik. Konflik-konflik tersebut apabila dibiarkan saja dapat menimbulkan disintegrasi bangsa. Oleh karena itu, lebih baik dalam memberikan komentar menggunakan bahasa yang santun yang membuat mitra tutur termotivasi.

\section{Menggunakan Penanda Identitas dalam Berkomentar}

Penggunaan penanda identitas sebagai salah satu bentuk kesantunan yang dapat digunakan dalam berkomentar di media sosial. Penanda identitas yang dapat digunakan di antaranya dengan bentuk sapaan, dialek, dan jargon. Berikut ini komentar berkarakter yang menggunakan penanda identitas.

(3) Harga di kisaran segitu masih umum... maju terus pak de. (sirrussadj, 1-102018)

Konteks: Jokowi memantau harga kebutuhan bahan pokok seperti sayur, buah-buahan, dan daging di pasar Bogor, pasar tradisional di jalan Roda, Kota Bogor.

Tuturan data (3) merupakan komentar yang menggunakan penanda identitas. Hal ini dilakukan oleh penutur untuk membangun kedekatan penutur dengan mitra tutur. Penanda identitas yang digunakan penutur pada komentar di atas adalah kata pakde. Penanda identitas dalam tindak komunikasi sebagai strategi untuk memberikan penghargaan, dan memberikan kesan lebih santun kepada mitra tutur.

Penggunaan penanda identitas pakde pada komentar di atas sebagai strategi untuk menjalin kedekatan dengan mitra tutur. Menjalin kedekatan dengan mitra tutur dalam komunikasi sebagai strategi untuk mencapai tujuan komunikasi.

Komentar-komentar dengan menggunakan penanda identitas dalam media sosial dapat dipilih karena hal ini sebagai realisasi strategi kesantunan dalam bermedia. Melalui penanda identitas yang digunakan dalam komunikasi dapat terwujud keakraban dalam berkomunikasi. Melalui keakraban antara penutur dan mitra tutur akan terwujud komunikasi yang memilki kualitas baik. 


\section{Memberikan Pertanyaan dalam Berkomentar}

Memberikan pertanyaan kepada mitra tutur dalam suatu komentar sebagai strategi kesantunan positif. Selain itu, memberikan pertanyaan sebagai salah satu bentuk perhatian kepada mitra tutur dan membangun kedekatan dengan mitra tutur. Memberikan pertanyaan kepada mitra tutur dalam penelitian ini bertujuan meminta penjelasan.

(4) Asalamualaikum pak Jokowi... perkenalkan nama saya maya asal kecamatan timpeh kabupaten Dharmasraya Sumatra Barat... mau bertanya kenapa ya pak harga sawit turun drastis hanya 900/ $\mathrm{kg}$ nya yang. kami biasanya 1300/kg (jhenout, 1-10-2018)

Konteks: Jokowi memantau harga kebutuhan bahan pokok seperti sayur, buah-buahan, dan daging di pasar Bogor, pasar tradisional di jalan Roda, Kota Bogor.

Tuturan data (4) merupakan komentar yang memiliki nilai kesantunan positif. Kesantunan pada komentar tersebut direalisasikan dengan cara penutur bertanya mengenai tindakan yang dilakukan oleh mitra tutur. Pertanyaan yang diberikan kepada mitra tutur adalah pertanyaan yang relevan dengan pernyataan mitra tutur. Selain itu sebaiknya dalam memberikan pertanyaan tidak menjebak mitra tutur untuk menjawab hal-hal yang mencelakakan dirinya.

Kesantunan positif dengan memberikan pertanyaan mitra tutur dalam berkomunikasi dapat dijadikan sebagai contoh dalam bermedia secara bijaksana. Menggunakan media dengan cara bertanya atau mengklarifikasi sesuatu hal kepada yang bersangkutan merupakan hal yang menunjukkan karakter yang bijaksana daripada menuduh tanpa klarifikasi dengan mitra tutur. Mengklarifikasi suatu hal hendaknya dengan bukti-bukti yang akurat.

\section{Melibatkan Mitra Tutur dalam Berkomentar}

Melibatkan mitra tutur dalam aktivitas tuturan merupakan strategi kesantunan membangun kedekatan antara penutur dan mitra tutur. Melalui kedekatan tersebut akan terwujud tujuan komunikasi dengan berkualitas. Berikut ini komentar berdaya kesantunan positif dengan melibatkan mitra tutur dalam aktivitas tuturan.

(5) Pak presidenku, semoga selalu diparingi kesehatan, keselamatan dan hati yang luas untuk memanfaatkan nggeh Pak. Masih banyak orang-orang baik yang sibuk mendoakan kebaikan untuk bapak dan bangsa melindungi kita. Semoga Allah SWT melindungi kita, saudara/I kita dimana pun berada (ayumiakihit022, 11-10-2018).

Konteks: Jokowi menyerahkan beasiswa dari pemerintah kepada tujuh orang yang mewakili 5.144 mahasiswa penerima beasiswa di NTB.

Tuturan data (5) merupakan komentar akun instagram ayumiakihit022 yang mengomentari postingan Jokowi yang menyerahkan beasiswa kepada mahasiswa di NTB. Komentar tersebut merupakan komentar yang memiliki kesantunan positif. Wujud kesantunan positif yang digunakan penutur direalisasikan melalui penggunaan kata kita. Kata kita sebagai bentuk kesantunan dengan melibatkan mitra tutur dalam komunikasi yang berlangsung.

Komentar santun pada data di atas merupakan contoh yang baik dalam bermedia sosial. Mitra tutur merasa senang apabila dilibatkan dalam aktivitas komunikasi. Artinya, komunikasi yang sedang berlangsung adalah komunikasi dua arah antara penutur dan mitra tutur bukan sebaliknya komunikasi yakni komunikasi tunggal. Oleh karena itu, sebaiknya dalam berkomentar warganet menggunakan bentuk-bentuk kesantunan seperti data (5). 


\section{Mengintensifkan Perhatian kepada Mitra Tutur dan Berkomentar}

Memberikan perhatian secara intensif kepada mitra tutur merupakan komentar yang menunjukkan kesantunan. Mitra tutur akan merasa senang apabila diperhatikan secara intensif. Warganet dalam berkomentar akan lebih aman apabila memberikan perhatian secara intensif kepada mitra tutur. Hal ini dapat dilakukan dengan cara memberikan dukungan terhadap sesuatu hal yang dikerjakan oleh mitra tutur. Berikut ini komentar santun yang direalisasikan dengan mengintensifkan perhatian kepada mitra tutur.

(6) Asian Games 2018 menjadi awal kebangkitan olah raga Indonesia (Okadewantara. 8-10-2018)

Konteks: Jokowi menyambut kedatangan atlet nasional Eko Yuli Irawan, yang bertandang ke Istana Merdeka, sepulang dari kejuaraan dunia angkat besi di Turkmenistan. Eko merebut medali emas di kelas 61 kilogram sekaligus memecahkan rekor dunia.

Tuturan data (6) adalah komentar yang mengintensifkan perhatian kepada mitra tutur. Hal ini terlihat pada komentar yang disampaikan pemilik akun instagram okadewantara. Komentar tersebut menyatakan bahwa Asian Games 2018 menjadi awal kebangkitan olah raga di Indonesia. Hal ini memberikan perhatian secara intensif karena mitra tutur mengunduh mengenai keberhasilan atlet Indonesia yang memecahkan rekor dunia. Dengan demikian, komentar tersebut mengintensifkan perhatian terhadap tuturan yang disampaikan mitra tutur.

Komentar-komentar media sosial yang memberikan perhatian kepada mitra tutur sebagai strategi dalam membangun komunikasi yang berkualitas. Mitra tutur pada dasarnya akan menjadi senang dengan cara diberikan perhatian. Oleh karena itu, dalam berkomunikasi pada media ada baiknya memperhatikan kesukaan mitra tutur.

\section{PENUTUP}

Berdasarkan hasil dan pembahasan di atas dapat disimpulkan bahwa strategi bermedia sosial dapat direalisasikan melalui kesantunan positif dan dapat diwujudkan dengan memperhatikan keinginan mitra tutur, menunjukkan rasa percaya diri, menggunakan penanda identitas, memberikan pertanyaan yang tidak menjebak, melibatkan mitra tutur dalam aktivitas tuturan, dan mengintensifkan perhatian kepada mitra tutur dalam tuturan. Wujud kesantunan positif tersebut dapat dipilih dalam bermedia sosial. Oleh karena itu, sebaiknya warganet dalam bermedia sosial mengedepankan tindak kesantunan berbahasa baik memberi saran, masukan, komentar, dan kritik kepada mitra tutur. Komunikasi yang dibangun berlandaskan kesantunan merupakan komunikasi yang humanis. Langkah yang selanjutnya dapat dilakukan adalah membangun budaya literasi media sosial berbasis kesantunan berbahasa. Hal ini sebagai gerakan literasi digital yang bertujuan membangun karakter pengguna media sosial. Pembangunan karakter melalui media sosial dilakukan secara terus menerus dengan mengedepankan kesantunan bermedia sosial.

\section{DAFTAR PUSTAKA}

Akbar, M. H. (2017) Kesantunan dan Ketidaksantuan Berbahasa Masyarakat Sunda dalam Dialog Percakapan pada Acara Kunjungan Keluarga di Beberapa Tempat di Jawa Barat. Jurnal Al-Tsaqafa, 14 (01), 95-120.

Cahyaningrum, F. A. B. S. (2018) Kesantunan Berbahasa Siswa dalam Berdiskusi. Madah, 9 (1), 45-54.

Creswell, J. W. (2014), Research design: Qualitative, quantitative, and mixed methods approaches. America: United States of America. 
Hari Kusmanto, Perwujudan Tindak Kesantunan ...

Doko, Y. D., \& Warmadewa, U. (2017) Kesantunan berbahasa dalam kumpulan cerita rakyat nusa tenggara timur. RETORIKA: Jurnal Ilmu Bahasa, 3 (1), 159-169.

Fauziati, E. (2016), Applied Linguistics Principle of Foreign Language Teaching, Learning, and Researching. Surakarta: Era Pustaka Utama.

Febriadina, Z. F., Sumarwati, \& Sumarlam. (2018). Male and Female Student' Politeness in Sragen, Central Java. Humanus, 17 (1), 73-83. https://doi.org/10.24036/ humanus.v17i1.8429

Hamidah. (2017) Kesantunan Berbahasa sebagai Upaya Meraih Komunikasi yang Efektif. Arkhais, 08 (1), 1-9. https:// doi.org/DOI: https://doi.org/10.21009/ ARKHAIS.081.04

Inderasari, E., Achsani, F., \& Lestari, B. (2018) Bahasa Sarkasme Netizen dalam Komentar Akun Instagram "Lambe Turah." Semantik, 7 (1), 90-98. https:// doi.org/10.22460/semantik.vXiX.XXX

Kuntarto, eko. (2016) Kesantunan Berbahasa Ditinjau dari Prespektif Kecerdasan Majemuk. Jurnal Ilmiah Universitas Batanghari Jambi, 16 (2), 58-73.

Kurniadi, F., Hilaliyah, H., \& Hapsari, S. N. (2018) Membangun Karakter Peserta Didik Melalui Kesantunan Berbahasa. AKSIOLIGIYA: Jurnal Pengabdian Kepada Masyarakat, 2 (1), 1-7. https:// doi.org/DOI: http://dx.doi.org/10.30651/ aks.v2i1

Kusmanto, H. (2019) Tindak Tutur Ilokusioner Ekspresif Plesetan Nama Kota di Jawa Tengah: Kajian Pragmatik. Jurnal Pendidikan Bahasa Dan Sastra Indonesia, 4(September), 127-132.

Kusmanto, H., \& Purbawati, C. (2019) Impoliteness Commenting on Sosial Media Instagram: Studi Politico Pragmatic. Jurnal Kata: Penelitian Tentang Ilmu Bahasa Dan Sastra, 3(2), 217-227.

Kusno, A., \& Rahman, A. (2016) BentukBentuk Pelanggaran Prinsip Kesopanan dalam Ceramah Keagamaan. LiNGUA: Jurnal Ilmu Bahasa Dan Sastra, 11(2), 103-115. https://doi.org/10.18860/ling. v11i2.3502

Mahsun, M. S. (2014), Metode Penelitian Bahasa Metode Penelitian Bahasa: Tahapan Strategi Metode dan Tekniknya. Jakarta: Raja Grafindo Persada.

Nugraha, A. P. (2017) Analisis Ketidaksantunan dalam Perang Kicauan Antarkubu Calon Presiden Amerika Serikat Pada Pilpres 2016. Etnolingual, 1(1), 169-188.

Praptiningsih, N. A., \& Handayani, A. K. (2017) Implikasi Nettiquette sebagai Adab Bermedia Sosial dalam Dakwah Religi. Journal Uhamka, 8(2), 144-162.

Rahmi, A. (2017) Community Development dengan Bermedia Secara Santun. Islamic Cominiication Journal, 2(1), 58-79.

Sandra, M., \& Dewi, R. (2019) Islam dan Etika Bermedia (Kajian Etika Komunikasi Netizen di Media Sosial Instagram Dalam Perspektif Islam). Research Fair Unisri, 3(1), 139-142.

Setiawaty, R., Murdiyanto, D., Putra, L., \& Amin, M. K. (2018) Pengidentifikasian dan Pengkreasian Ungkapan Vulgar pada Komentar Akun Facebook Presiden Joko Widodo Sebagai Inovasi Bahan Ajar. In Prosiding Seminar Nasional Geotik II (pp. 28-38).

Sudaryanto. (2015), Metode dan Aneka Teknik Analisis Bahasa: Pengantar Penelitian Wahana Kebudayaan Secara Linguistik. Yogyakarta: Sanata Dharma University Press.

Syaifudin, Z. K. (2017) Implikatur dan Kesantunan Positif Tuturan Jokowi dalam Talkshow Mata Najwa dan Implementasinya sebagai Bahan Ajar Bahasa Indonesia di SMK. Jurnal Penelitian Humaniora, 14(1), 5570. https://doi.org/DOI: https://doi. org/10.23917/humaniora.v14i1.886 
Tojo, H., \& Takagi, A. (2017) Trends in Qualitative Research in Three Major Language Teaching and Learning Journals, 2006-2015. International Journal of English Language Teaching, 4(1), 37. https://doi.org/10.5430/ijelt.v4n1p37

Ulum, D. E. L., \& Kusmanto, H. (2018) Disfemia pada Komentar Akun Instagram Mimi.Peri. In Seminar Kajian Bahasa, Sastra, dan Pengajarannya V (pp. 232237).
Zamzani. (2010) Pengembangan Alat Ukur Kesantunan Behasa Indonesia dalam Interaksi Sosial Bersemuka dan Non Bersemuka. LITERA, 5(1976), 265 288. https://doi.org/http://dx.doi.org/10. 21831/ltr.v10i1.1171

Zurqoni, Z., Retnawati, H., Apino, E., \& Anazifa, R. D. (2019). Impact ofCharacter Education Implementation: a Goal-Free Evaluation. Problems of Education in the 21st Century, 76(6), 881-899. https://doi. org $/ 10.33225 / \mathrm{pec} / 18.76 .881$ 